\title{
ATP Receptor Regulation of Adenylate Cyclase and Protein Kinase C Activity in Cultured Renal LLC-PK Cells $_{1}$
}

Robert J. Anderson, Ruth Breckon, and Bradley S. Dixon

Medical Service, Denver Veterans Affairs Medical Center; and Department of Medicine,

University of Colorado Health Sciences Center, Denver, Colorado 80262

\begin{abstract}
In cultured intact $L L C-P K_{1}$ renal epithelial cells, a nonhydrolyzable ATP analogue, ATP $\gamma \mathrm{S}$, inhibits AVP-stimulated cAMP formation. In LLC-PK 1 membranes, several ATP analogues inhibit basal, GTP-, forskolin-, and AVP-stimulated adenylate cyclase activity in a dose-dependent manner. The rank order potency of inhibition by ATP analogues suggests that a $P_{2 y}$ type of ATP receptor is involved in this inhibition. The compound ATP $\gamma \mathbf{S}$ inhibits agonist-stimulated adenylate cyclase activity in solubilized and in isobutylmethylxanthine (IBMX) and quinacrine pretreated membranes, suggesting that ATP $\gamma S$ inhibition occurs independent of AVP and $A_{1}$ adenosine receptors and of phospholipase $A_{2}$ activity. The ATP $\gamma S$ inhibition of AVP-stimulated adenylate cyclase activity is not affected by pertussis toxin but is attenuated by GDP $\beta S$, suggesting a possible role for a pertussis toxin insensitive $G$ protein in the inhibition. Exposure of intact LLC-PK cells to $A T P \gamma S$ results in a significant increase in protein kinase $C$ activity. However, neither of two protein kinase $\mathrm{C}$ inhibitors (staurosporine and H-7) prevents ATPrS inhibition of AVPstimulated adenylate cyclase activity, suggesting that this inhibition occurs by a protein kinase $\mathbf{C}$ independent mechanism. These findings suggest the presence of functional $P_{2 y}$ purinoceptors coupled to two signal transduction pathways in cultured renal epithelial cells. The effect of $P_{2 y}$ purinoceptors to inhibit AVP-stimulated adenylate cyclase activity may be mediated, at least in part, by a pertussis toxin insensitive $G$ protein. (J. Clin. Invest. 1991. 87:1732-1738.) Key words: purinoceptors • vasopressin • adenosine triphosphate • cyclic AMP
\end{abstract}

\section{Introduction}

Extracellular purines such as adenosine and adenine nucleotides such as ATP interact with cell surface receptors to regulate several physiologic processes $(1,2)$. Two general classes of purinergic receptors exist (1-3). One class is activated by adenosine and blocked by methylxanthines. These receptors are coupled to adenylate cyclase via $G$ proteins in an inhibitory $\left(A_{1}\right.$ receptor) and a stimulatory ( $A_{2}$ receptor) fashion. A second class of purinergic receptors is activated by ATP and is insensitive to methylxanthines. This class of receptor, referred to as $\mathbf{P}_{\mathbf{2}}$ purinergic receptors, can be further subdivided into $P_{2 x}$ and $P_{2 y}$

Address correspondence and reprint requests to Robert J. Anderson, Medical Service (111), Veterans Administration Medical Center, 1055 Clermont Street, Denver, CO 80220.

Received for publication 31 May 1990 and in revised form 28 December 1990.

The Journal of Clinical Investigation, Inc.

Volume 87, May 1991, 1732-1738 subtypes based on relative potencies of synthetic ATP analogues (3). There is limited information on the biochemical events involved in $\mathbf{P}_{2}$ receptor action. In some cell types, $\mathbf{P}_{2}$ receptors appear to be coupled via $G$ proteins to activation of phosphoinositide- and phosphatidylcholine-specific phospholipase $C$ activity (4-8).

Several studies have delineated an important role for $A_{1}$ and possibly $A_{2}$ adenosine receptors in regulation of renal blood flow, glomerular filtration rate, renin secretion, and renal tubular transport processes (9-15). There is, however, very limited information on the presence and functional significance of ATP responsive $P_{2}$ purinergic receptors on renal epithelial cells (16-21). These studies were undertaken to examine the effect of several ATP analogues on biochemical responses in cultured renal epithelial LLC-PK ${ }_{1}$ cells. Our results suggest the presence of $P_{2 y}$ purinergic receptors coupled to both inhibition of adenylate cyclase and stimulation of protein kinase $\mathrm{C}$ activity in these cells.

\section{Methods}

Materials. Arginine vasopressin, guanosine triphosphate (GTP), guanosine 5'-O-(2-thiodiphosphate, [GDP $\left.\beta S]^{\prime}\right)$, staurosporine, quinacrine dihydrochloride and $4 \beta$-phorbol 12-myristate 13-acetate (PMA) were obtained from Sigma Chemical Co., St. Louis, MO. Adenosine 5'-O-3thiotriphosphate, (ATP $\gamma \mathrm{S}), \beta, \gamma$-methyleneadenosine 5 -triphosphate, ( $\beta, \gamma \mathrm{ATP})$, and 2-methylthioadenosine 5'-triphosphosate, (2 MeATP) were purchased from Research Biochemicals, Natick, MA. Phosphatidylserine, diolein, and 1-oleoyl-2-acetyl-glycerol (OAG) were purchased from Avanti Polar Lipids, Inc., Birmingham, AL. Forskolin, 3-isobutyl-1-methylxanthine (IBMX) and H-7 (1-15-isoquinolonylsulfonyl)-2-methylpiperazine) were purchased from Calbiochem-Behring Corp., San Diego, CA. Pertussis toxin was purchased from List and RO-201724 was obtained from Biomol Research Labs, Inc. $\left[\alpha{ }^{32} \mathrm{P}\right]-$ ATP (30-40 Ci/mmol), [ $\left.\gamma-{ }^{32} \mathrm{P}\right]$ ATP $(25-35 \mathrm{Ci} / \mathrm{mmol}),\left[{ }^{3} \mathrm{H}\right] \mathrm{cAMP}$, and the cAMP radioimmunoassay kits were obtained from DuPont-New England Nuclear.

Cell culture and enzyme assays. LLC-PK ${ }_{1}$ cells, crude membranes, and particulate and soluble cell fractions were prepared as previously described (22-24). Adenylate cyclase, cAMP phosphodiesterase, cAMP, protein kinase $C$, and total protein assays were performed exactly as described in recent publications from our laboratory (22-26).

Statistical analyses. For adenylate cyclase analyses, all assays were performed in triplicate and the mean of the three determinations considered an $n$ of 1 . For cAMP analyses, each tissue culture well was considered an $n$ of 1 . All calculations and analyses were carried out using an ATT PC-6300 desktop computer (Iverson, NJ) and ABSTAT software (Parker, $\mathrm{CO}$ ). All data are expressed as the mean \pm SE. Statistical analyses were performed using paired or unpaired Student's $t$ test and analysis of variance where appropriate. A $P$ value $<0.05$ is considered significant.

1. Abbreviations used in this paper: GDP $\beta$, guanosine thiodiphosphate staurosporine; IBMX, isobutyl methylxanthine; MeATP, methylthioadenosine triphosphate; OAG, oleoyl-acetyl-glycerol. 


\section{Results}

Effect of ATP $\mathrm{S}$ on AVP-stimulated cAMP formation in intact $L L C-P K_{1}$ cells. In initial studies, we measured the effect of ATP $\gamma \mathrm{S}$, a nonhydrolyzable ATP analogue with known $\mathrm{P}_{2 \mathrm{y}}$ receptor site activity, on hormone-stimulated cAMP formation in intact LLC-PK ${ }_{1}$ cells. Cells were pretreated for $30 \mathrm{~min}$ with RO-201724 $\left(10^{-3} \mathrm{M}\right)$, a phosphodiesterase inhibitor that is not an adenosine receptor antagonist. As shown in Table I, ATP $\gamma$ S $\left(10^{-4} \mathrm{M}\right)$ significantly inhibits AVP-stimulated cAMP formation in intact LLC-PK ${ }_{1}$ cells.

Effect of ATP analogues on basal and agonist-stimulated adenylate cyclase activity in $L L C-P K_{1}$ crude cell membranes. Our cAMP results suggest that ATP $\gamma \mathrm{S}$ inhibits cAMP formation. To determine if ATP $\gamma \mathrm{S}$ inhibits agonist-stimulated adenylate cyclase activity, the studies demonstrated in Fig. 1 were carried out in LLC-PK 1 crude membranes. At concentrations greater than $10^{-9} \mathrm{M}, \mathrm{ATP} \gamma \mathrm{S}$ significantly inhibits arginine vasopressin-stimulated adenylate cyclase activity. Between $10^{-4}$ and $10^{-8} \mathrm{M} \mathrm{ATP} \gamma \mathrm{S}, 25-40 \%$ inhibition occurs while $90 \%$ inhibition occurs at $10^{-3} \mathrm{M}$.

To better delineate the mechanism of ATP-induced inhibition of adenylate cyclase activity, we measured the effects of three ATP analogues $(\beta, \gamma \mathrm{ATP}, 2 \mathrm{MeATP}$, and ATP $\gamma \mathrm{S})$ on adenylate cyclase activity in crude $L L C-P_{1}$ membranes in paired studies. These analogues were selected since previous studies suggest that the $P_{2 y}$ receptor subtype expresses a potency order of 2 MeATP $\gg$ ATP $>\beta, \gamma$ ATP, whereas the $\mathrm{P}_{2 \mathrm{x}}$ receptor subtype expresses a rank order of potency of $\beta, \gamma \mathrm{ATP}$ $>$ ATP $>2$ MeATP (1-3). The results of synthetic ATP analogues on basal-, GTP-, forskolin-, and AVP-stimulated adenylate cyclase activity are in Figs. 2-5. All ATP analogues exert dose-dependent effects to significantly inhibit basal and agonist stimulated enzyme activity (Figs. 2 and 3). In general, 2 MeATP was the most potent inhibiting analogue. ATP $\gamma$ S at $10^{-4}$ inhibited the effects of maximal and submaximal concentrations of AVP and forskolin to stimulate adenylate cyclase activity (Figs. $4 A$ and $5 A$ ).

Role of $A V P$ and $A_{1}$ adenosine receptors and of phospholipase $A_{2}$ in $A T P \gamma S$ inhibition of adenylate cyclase activity in $L L C$ - $P K_{1}$ cell membranes. To better delineate the mechanism of ATP inhibition of adenylate cyclase activity, LLC-PK crude membranes were solubilized with $0.2 \%$ Lubrol PX (Table II).

Table I. Inhibition of AVP-stimulated cAMP Formation by $A T P \gamma S\left(10^{-4} M\right)$ in Intact $L L C-P K_{1}$ Cells

\begin{tabular}{ccc}
\hline & \multicolumn{2}{c}{$\begin{array}{c}\text { Percentage increase } \\
\text { from basal cAMP }\end{array}$} \\
\cline { 2 - 3 } Concentration of AVP & $(-)$ ATP $\gamma$ S & $(+)$ ATP $\gamma$ S \\
\hline$-\log M$ & & \\
9 & $-6 \pm 1$ & $-9 \pm 1$ \\
8 & $179 \pm 43$ & $20 \pm 5^{*}$ \\
7 & $314 \pm 23$ & $39 \pm 10^{*}$ \\
\hline
\end{tabular}

Cells were pretreated for $30 \mathrm{~min}$ with $10^{-3} \mathrm{M}$ RO 201724 before exposure to ATP $\gamma$ S and AVP. The concentration of cAMP in RO 201724-pretreated cells before exposure to ATP $\gamma S$ and AVP ranged from 51.7 to $116.3 \mathrm{fmol} / \mu \mathrm{g}$ protein per min. The data represent the percentage change from six measurements performed under all conditions in two separate paired experiments. ${ }^{*} P<0.05$ when compared with paired control.

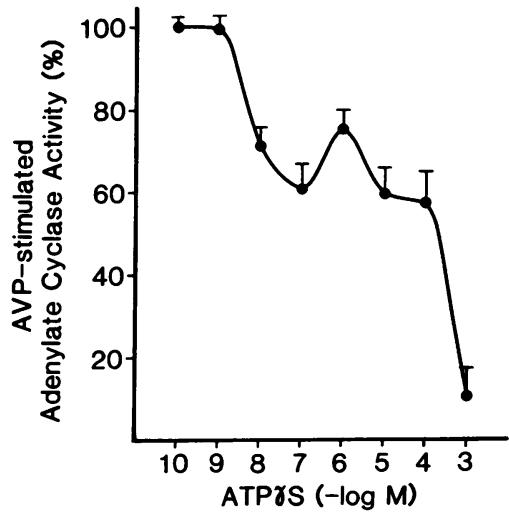

Extensive Lubrol PX dose-ranging studies were done that found that lower concentrations did not inhibit AVP-stimulated adenylate cyclase activity and higher concentrations of Lubrol abolished GTP- and forskolin-stimulated adenylate cyclase activity. Solubilization of LLC-PK 1 membranes significantly reduces $(P<0.05)$ basal, GTP-, and forskolin-stimulated enzyme activity. In solubilized membranes, AVP no longer stimulates adenylate cyclase activity, while both GTP and forskolin significantly $(P<0.05)$ increase $(4.5-$ and $5.8-$ fold, respectively) enzyme activity over basal values. ATP $\gamma S$ $\left(10^{-4} \mathrm{M}\right)$ significantly inhibits forskolin-stimulated adenylate cyclase activity by $56 \%$ in intact and $48 \%$ in solubilized membranes. These results suggest that ATP $\gamma \mathrm{S}$ does not require an intact plasma membrane environment that contains a functional AVP receptor to inhibit adenylate cyclase activity.

ATP $\gamma \mathrm{S}$ is a chemically stable ATP analogue that may be resistant to ecto-nucleotidase-mediated degradation to adenosine. However, to insure that $\mathrm{ATP} \gamma \mathrm{S}$ inhibition of adenylate cyclase is not mediated by an $A_{1}$ adenosine receptor, the effect of IBMX, an $A_{1}$ type adenosine receptor antagonist, was examined (Fig. 6, panel $B$ ). ATP $\gamma$ S inhibition of AVP-stimulated adenylate cyclase activity is the same in the presence and absence of IBMX suggesting an $A_{1}$ adenosine receptor-independent effect.

In some cell types, $\mathrm{P}_{2}$ receptor agonists stimulate phospholipase $A_{2}$ activity (27). Activation of phospholipase $A_{2}$ could generate arachidonic acid metabolites which potentially inhibit

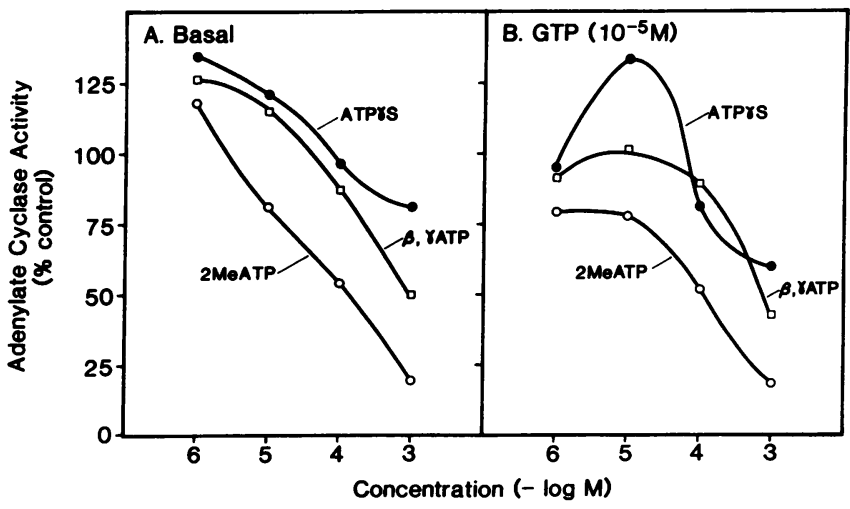

Figure 2. Dose-dependent effects of ATP analogues on basal $(A)$ and GTP- $(B)$ stimulated adenylate cyclase activity in LLC-PK 1 membranes. The values represent the mean of four separate assays performed in triplicate. The SEM values for individual data points ranged from 2 to $5 \%$. 


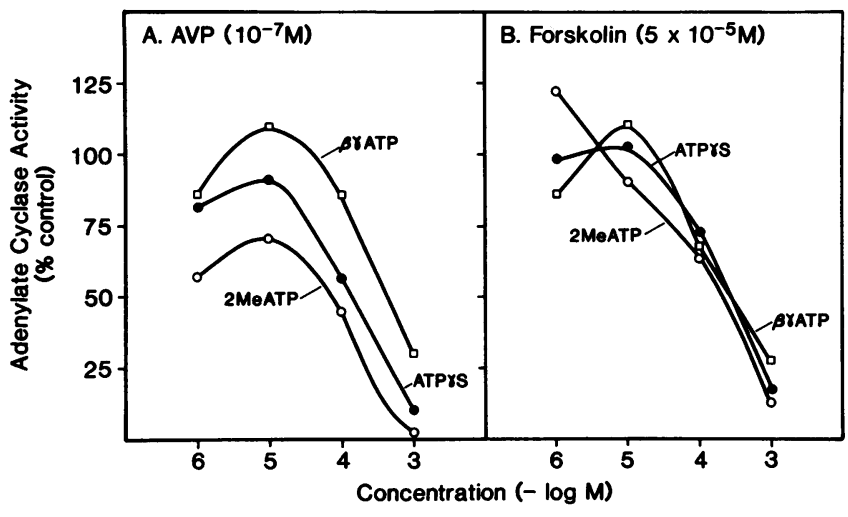

Figure 3. Dose-dependent effects of ATP analgogues on AVP- $(A)$ and forskolin- $(B)$ stimulated adenylate cyclase activity in LLC-PK membranes. The values represent the mean of four separate assays done in triplicate. The SEM value for individual data points ranged from 1 to $6 \%$.

adenylate cyclase activity. To determine if ATP $\gamma$ S inhibition of adenylate cyclase activity is mediated via phospholipase $A_{2}$, the effects of $10^{-4} \mathrm{M}$ quinacrine, a phospholipase $\mathrm{A}_{2}$ inhibitor, were studied (Fig. $6 A$ ). ATP $\gamma \mathrm{S}$ inhibition of AVP-stimulated adenylate cyclase activity is the same in the presence and absence of quinacrine suggesting a phospholipase $A_{2}$ independent effect.

Role of $G$ proteins in ATPYS inhibition of agonist-stimulated adenylate cyclase activity in $L L C-P K_{1}$ membranes. Previous studies suggest that $P_{2 y}$ receptors may be coupled to inhibition of adenylate cyclase activity via a GTP binding protein $(5,7,28)$. We therefore examined the effect of ATP $\gamma S$ on AVP- and forskolin-stimulated adenylate cyclase activity in the presence and absence of pretreatment with $1.0 \mu \mathrm{g} / \mathrm{ml}$ pertussis toxin for $18 \mathrm{~h}$ (Figs. 4 and 5). Pertussis toxin ADP ribosylates the $\alpha$ subunit thereby inactivating a $\mathrm{G}$ protein linked to inhibition of adenylate cyclase activity. Pertussis toxin significantly potentiates AVP- and forskolin-stimulated adenylate cyclase activity. However, the effect of ATP $\gamma \mathrm{S}$ to inhibit AVP- and

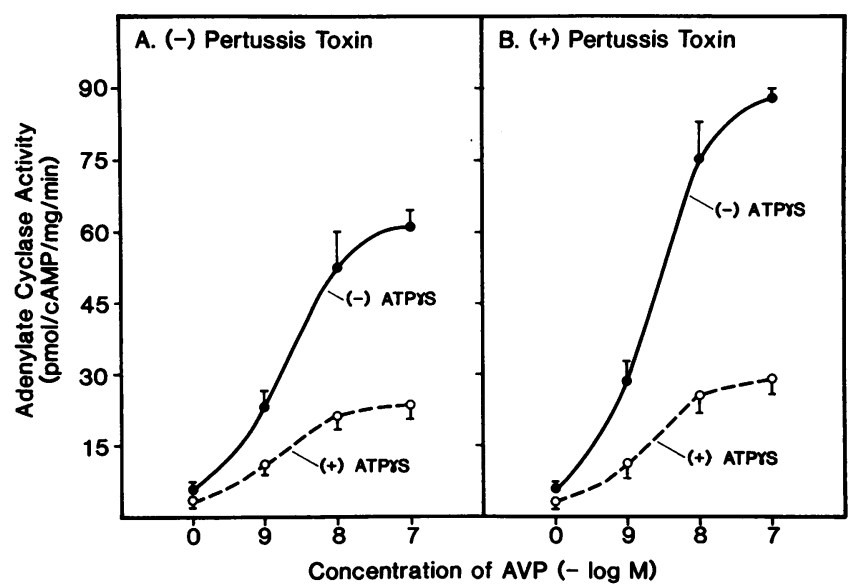

Figure 4. Effects of ATP $\gamma \mathrm{S}\left(10^{-4} \mathrm{M}\right)$ on AVP-stimulated adenylate cyclase activity in LLC-PK 1 membranes in the absence $(A)$ and presence $(B)$ of pertussis toxin pretreatment $(1 \mu \mathrm{g} / \mathrm{ml}$ for $18 \mathrm{~h})$. The values represent the mean \pm SEM of three to four paired assays done in triplicate.

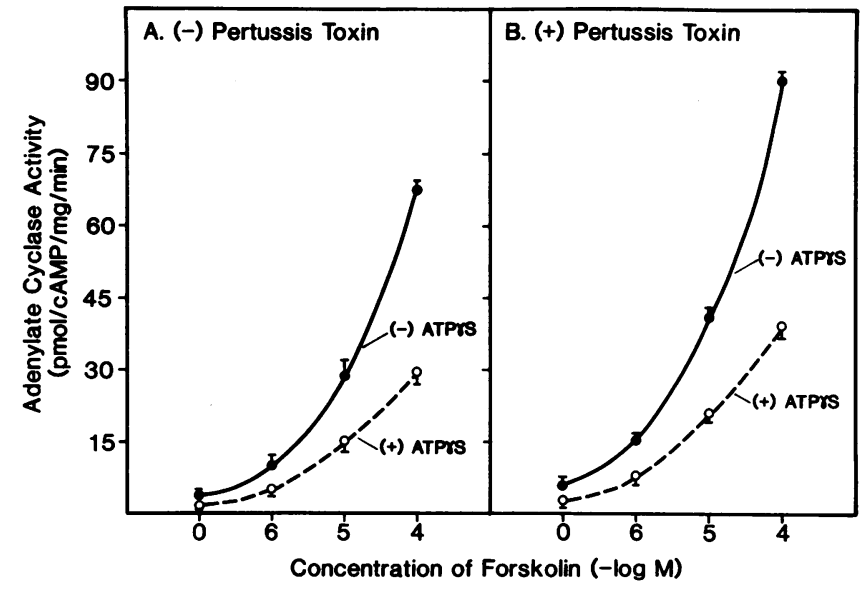

Figure 5. Effect of ATP $\gamma \mathrm{S}\left(10^{-4} \mathrm{M}\right)$ on forskolin-stimulated adenylate cyclase activity in LLC-PK 1 membranes in the absence $(A)$ and presence $(B)$ of pertussis toxin pretreatment $(1 \mu \mathrm{g} / \mathrm{ml}$ for $18 \mathrm{~h})$. The values represent the mean $\pm \mathrm{SEM}$ of four paired assays done in triplicate.

forskolin-stimulated adenylate cyclase activity was the same in the presence and absence of pertussis toxin. Similar results were observed with 10.0 and $100.0 \mu \mathrm{g} / \mathrm{ml}$ of pertussis toxin.

Further studies were done to evaluate the possibility that the effect of ATP $\gamma \mathrm{S}$ to inhibit adenylate cyclase activity is mediated by a pertussis toxin-insensitive $G$ protein. In these studies, we used GDP $\beta S$, a stable analogue of GDP which prevents $\mathrm{G}$ protein activation by preventing dissociation of the $\alpha$ sub-

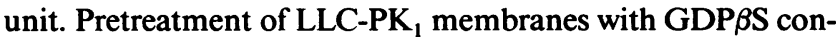
sistently and significantly reduced (by $\sim 50 \%$ ) the effect of ATP $\gamma$ S to inhibit AVP- and forskolin-stimulated adenylate cyclase activity (Table III). Together, these results suggest that the inhibitory effect of ATP $\gamma \mathrm{S}$ on AVP- and forskolin-stimulated adenylate cyclase activity may be mediated in part by a pertussis toxin-insensitive $\mathrm{G}$ protein.

Role of protein kinase $C$ in $A T P \gamma S$ inhibition of agoniststimulated adenylate cyclase activity in LLC-PK, cells. In many cells, $P_{2 y}$ purinergic receptors stimulate phospholipase C-catalyzed phosphoinositide hydrolysis and/or calcium mobilization $(5-7,28)$. To our knowledge, an effect of $P_{2 y}$ receptor

Table II. Effect of Lubrol PX on Adenylate Cyclase Activity in LLC-PK, Membranes

\begin{tabular}{lcc}
\hline & \multicolumn{2}{c}{ Adenylate cyclase activity } \\
\cline { 2 - 3 } \multicolumn{1}{c}{ Condition } & $\begin{array}{c}\text { Intact } \\
\text { membrane }\end{array}$ & $\begin{array}{c}\text { Solubilized } \\
\text { fraction }\end{array}$ \\
\hline & \multicolumn{2}{c}{ pmol/mg per min } \\
Basal & $3.2 \pm 0.3$ & $1.1 \pm 0.3$ \\
Arginine vasopressin $\left(10^{-7} \mathrm{M}\right)$ & $43.8 \pm 2.9$ & $1.7 \pm 0.5$ \\
GTP $\left(10^{-5} \mathrm{M}\right)$ & $11.4 \pm 0.9$ & $5.0 \pm 0.5$ \\
ATP $\gamma \mathrm{S}\left(10^{-4} \mathrm{M}\right)$ & $1.9 \pm 0.1$ & $1.8 \pm 0.1$ \\
Forskolin $\left(5 \times 10^{-5} \mathrm{M}\right)$ & $65.3 \pm 5.1$ & $6.4 \pm 0.7$ \\
Forskolin $\left(5 \times 10^{-5} \mathrm{M}\right)$ & & \\
$\quad+\mathrm{ATP} \gamma \mathrm{S}\left(10^{-4} \mathrm{M}\right)$ & $28.5 \pm 2.0$ & $3.1 \pm 0.6$
\end{tabular}

Values are mean $\pm \mathrm{SE}$ of four separate paired assays each done in triplicate. 


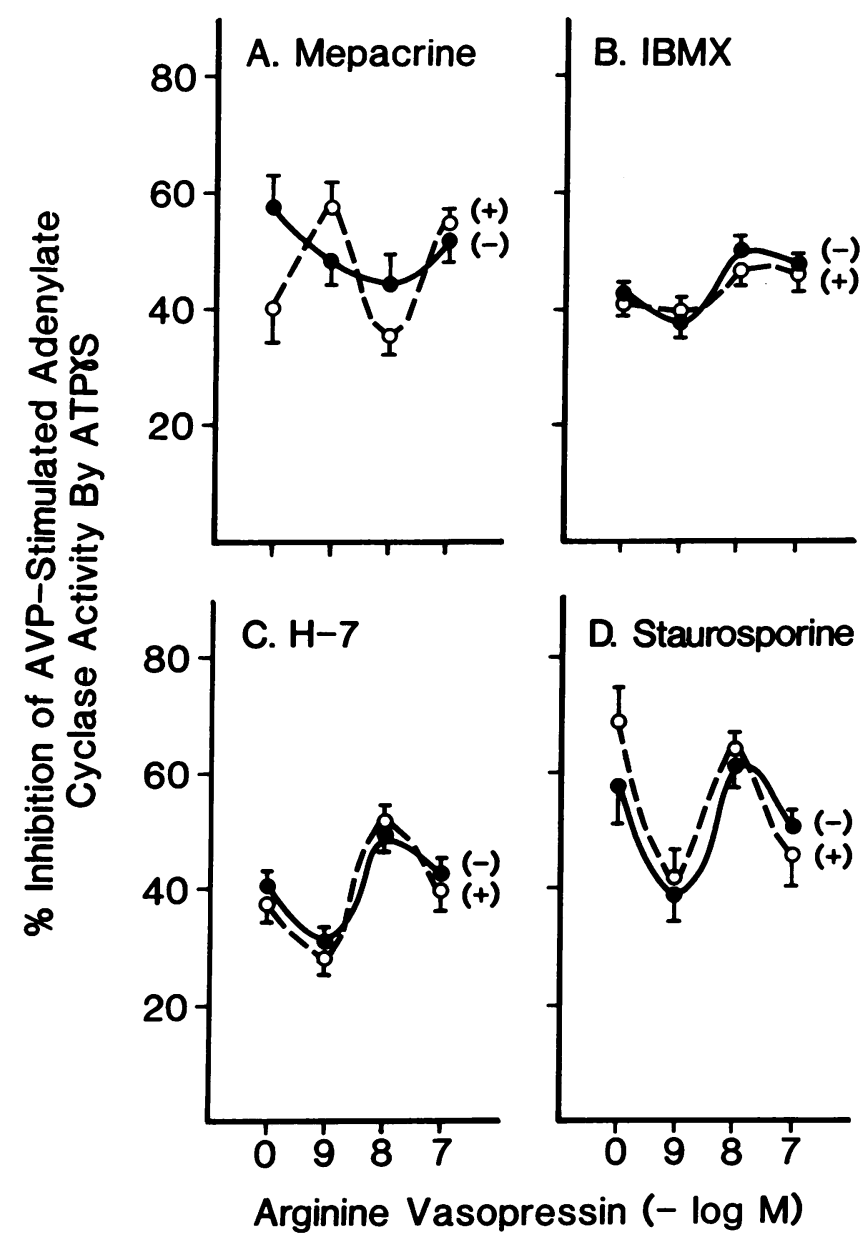

Figure 6. Effect of quinacrine (mepacrine, $\left.10^{-4} \mathrm{M}\right)(A)$, IBMX $\left(10^{-3}\right.$ M) $(B), \mathrm{H}-7\left(10^{-6} \mathrm{M}\right)(C)$, and staurosporine $\left(10^{-8} \mathrm{M}\right)(D)$ on ATP $\gamma \mathrm{S}$ $\left(10^{-4} \mathrm{M}\right)$ inhibition of AVP-stimulated adenylate cyclase activity in LLC-PK 1 membranes. The broken and solid lines represent ATP $\gamma$ S inhibition of AVP-stimulated adenylate cyclase activity in the presence and absence, respectively, of the test agents. Individual data points represent the mean \pm SEM of percentage inhibition of AVP-stimulated adenylate cyclase activity by ATP $\gamma$ S in three to four paired experiments performed in triplicate.

agonists to activate protein kinase $\mathrm{C}$ has not been directly demonstrated. We first determined that a calcium- and phospholipid-dependent protein kinase, which can be activated by the phorbol ester PMA and by the diacylglycerol diolein, is present in LLC-PK ${ }_{1}$ cells (Table IV). In these cells, PMA $\left(10^{-7} \mathrm{M}\right)$, a known activator of protein kinase $C(22,23)$, increased total protein kinase $C$ from a control value of $1.039 \pm 0.2$ to $1.590 \pm 0.19 \mathrm{nmol}^{32} \mathrm{P} \mathrm{mg}^{-1} \mathrm{~min}^{-1}(P<0.05)$, and translocated protein kinase $\mathrm{C}$ from a soluble to a particulate cell fraction ( $78 \pm 7$ to $32 \pm 5 \%$ soluble, $n=7, P<0.05$ ). To determine if ATP $\gamma \mathrm{S}$ activates protein kinase $\mathrm{C}$ in these cells, the studies

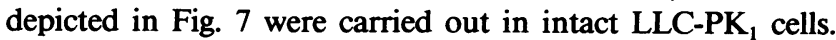
ATP $\gamma \mathrm{S}$ exerted dose-dependent effects of protein kinase $\mathrm{C}$ activity with concentrations of $10^{-10}$ through $10^{-5} \mathrm{M}$ significantly increasing activity over basal values. In these studies, basal protein kinase $C$ activity averaged $1.056 \pm 0.13 \mathrm{nmol}^{32} \mathrm{P} \mathrm{mg}^{-1}$ $\min ^{-1}$. At $10^{-10}$ through $10^{-3} \mathrm{M}, \mathrm{ATP} \gamma \mathrm{S}$ decreased the soluble and increased the particulate form of total protein kinase $\mathrm{C}$ activity by $10 \pm 2 \%$.
Table III. Effect of GDPBS on ATP $Y$-induced Inhibition of Adenylate Cyclase Activity in LLC-PK, Membranes

\begin{tabular}{llc}
\hline & \multicolumn{2}{c}{$\begin{array}{c}\text { Percentage inhibition } \\
\text { of adenylate cyclase } \\
\text { by } 10^{-4} \text { M ATP } \gamma\end{array}$} \\
\cline { 2 - 3 } \multicolumn{1}{c}{ Treatment } & GDPSS $(-)$ & GDP $\beta S(+)$ \\
\hline Forskolin $(M)$ & & \\
0 & $30 \pm 1$ & $0 \pm 2^{*}$ \\
$10^{-7}$ & $61 \pm 3$ & $22 \pm 2^{*}$ \\
$10^{-6}$ & $53 \pm 3$ & $29 \pm 10^{*}$ \\
$10^{-5}$ & $56 \pm 3$ & $29 \pm 9^{*}$ \\
$10^{-4}$ & $52 \pm 4$ & $27 \pm 7^{*}$ \\
Arginine vasopressin $(M)$ & & \\
0 & $75 \pm 2$ & $33 \pm 10^{*}$ \\
$10^{-9}$ & $45 \pm 10$ & $27 \pm 6^{*}$ \\
$10^{-8}$ & $74 \pm 5$ & $36 \pm 7^{*}$ \\
$10^{-7}$ & $53 \pm 4$ & $42 \pm 2^{*}$ \\
& &
\end{tabular}

Values are the percentage inhibition by $10^{-4}$ ATP $\gamma$ S of LLC-PK crude membrane adenylate cyclase activity measured under basal and under forskolin- and arginine vasopressin-stimulated conditions. The values represent the mean $\pm \mathrm{SE}$ of percentage inhibition obtained from four to six separate paired assays, each done in triplicate. ${ }^{*} P<0.05$ when compared with corresponding untreated values.

Previously, we have shown that activation and translocation of protein kinase $\mathrm{C}$ activity can induce a heterologous desensitization of adenylate cyclase activity in cultured renal epithelial cells $(22,23)$. To determine if $\mathrm{ATP} \gamma \mathrm{S}$ inhibition of adenylate cyclase activity is due to activation of protein kinase $C$, we examined the effect of two dissimilar protein kinase $C$ inhibitors, $\mathrm{H}-7\left(10^{-7} \mathrm{M}\right)$ and staurosporine $\left(10^{-8} \mathrm{M}\right)$ on $\operatorname{ATP}_{\gamma} \mathrm{S}\left(10^{-4} \mathrm{M}\right)$ inhibition of AVP-stimulated adenylate cyclase (Fig. 6, $C$ and $D$ ). Neither $\mathrm{H}-7$ nor staurosporine altered the effect of $10^{-4} \mathrm{M} \mathrm{ATP} \gamma \mathrm{S}$ to inhibit AVP-stimulated adenylate cyclase activity suggesting a protein kinase $\mathrm{C}$-independent effect. Since these studies were not performed with a concentration of $\mathrm{ATP} \gamma \mathrm{S}$ that maximally stimulated protein kinase $\mathrm{C}$ activity, additional experiments were performed. In five paired studies, ATP $\gamma \mathrm{S}_{\text {at }} 10^{-7} \mathrm{M}$ inhibited the effect of $10^{-8}$ and $10^{-7}$ M AVP to stimulate adenylate cyclase activity by $22 \pm 2 \%$ in the absence and $20 \pm 2 \%$ in the presence of $10^{-8} \mathrm{M}$ staurosporine. In another five paired studies, $10^{-7} \mathrm{M}$ ATP $\gamma \mathrm{S}$ inhibited the effect of $10^{-8}$ and $10^{-7} \mathrm{M}$ AVP to stimulate adenylate cyclase activity

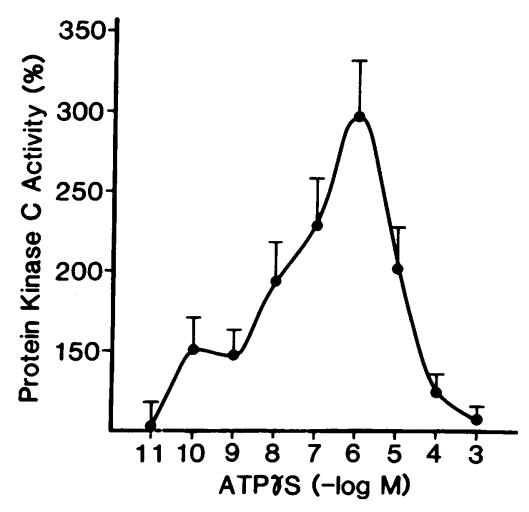

Figure 7. Dose-dependent effects of ATP $\gamma$ exposure in intact LLC$\mathrm{PK}_{1}$ cells on total protein kinase $\mathrm{C}$ activity. Individual data points represent the mean \pm SEM of six experiments. 
Table IV. Evidence for Protein Kinase C Activity in Intact $L L C-P K_{1}$ Cells

\begin{tabular}{|c|c|c|}
\hline \multirow[b]{2}{*}{ Assay addition } & \multicolumn{2}{|c|}{ Protein kinase $\mathrm{C}$ activity } \\
\hline & Cytosol & Particulate \\
\hline & \multicolumn{2}{|c|}{$\mathrm{nmol}{ }^{32} \mathrm{P} \cdot \mathrm{mg}^{-1} \cdot \mathrm{min}^{-1}$} \\
\hline None & $0.120 \pm 0.07$ & $0.177 \pm 0.07$ \\
\hline $\mathrm{CaCl}_{2}$ & $0.144 \pm 0.04$ & $0.091 \pm 0.04$ \\
\hline Phosphatidylserine + diolein & $0.473 \pm 0.12^{*}$ & $0.299 \pm 0.08^{*}$ \\
\hline $\mathrm{CaCl}_{2}+$ phosphatidylserine + diolein & $0.704 \pm 0.17^{*}$ & $0.388 \pm 0.07^{*}$ \\
\hline
\end{tabular}

Values are the mean $\pm \mathrm{SE}$ of five determinations. Assays were performed in the presence and absence of $1 \mathrm{mM} \mathrm{CaCl}_{2}, 60 \mu \mathrm{M}$ phosphatidylserine and $8 \mu \mathrm{M}$ diolein. ${ }^{*} P<0.05$ when compared with preceding entry in Table.

by $26 \pm 3 \%$ in the absence and $22 \pm 2 \%$ in the presence of $10^{-7}$ M H-7.

Effect of ATP $\mathrm{S}$ on $L L C-P K_{1}$ cellular CAMP phosphodiesterase activity. There is evidence that ATP can regulate cAMP hydrolysis $(29,30)$. We therefore examined the effect of ATP $\gamma$ S on cAMP phosphodiesterase activity in particulate and soluble fractions from LLC-PK 1 cells (Table V). ATP $\gamma \mathrm{S}$ at $10^{-3} \mathrm{M}$ reduced total and high affinity forms of cAMP phosphodiesterase activity by 35 and $26 \%$ respectively in a particulate fraction. In soluble fraction, $\mathrm{ATP} \gamma \mathrm{S}$ at $10^{-5}$ and $10^{-4} \mathrm{M}$ decreased total cAMP phosphodiesterase activity by $32 \%$.

\section{Discussion}

There is limited information on the presence and functional significance of ATP-responsive receptors on renal epithelial cells. In these studies, we find that the nonhydrolyzable ATP analogue, ATP $\gamma$ S, exerts a significant effect to inhibit AVPstimulated cAMP formation in intact LLC-PK $_{1}$ cells. Since these cells were pretreated with a cAMP phosphodiesterase inhibitor, the results suggest that ATP $\gamma$ S inhibits AVP-stimulated adenylate cyclase activity. We confirmed this by directly measuring adenylate cyclase activity in crude LLC-PK mem- $_{1}$ branes. In these studies, ATP and several analogues exert dosedependent effects to inhibit basal, GTP-, AVP-, and forskolin-

Table V. Effect of ATP $\mathrm{S}$ on cAMP Phosphodiesterase Activity from $L L C-P K_{1}$ Cells

\begin{tabular}{|c|c|c|c|c|}
\hline & \multicolumn{4}{|c|}{ cAMP phosphodiesterase activity (pmol/mg per $20 \mathrm{~min}$ ) } \\
\hline & \multicolumn{2}{|c|}{ Membrane } & \multicolumn{2}{|c|}{ Soluble } \\
\hline & Total & High affinity & Total & High affinity \\
\hline Basal & $9.3 \pm 3.6$ & $0.33 \pm 0.08$ & $33.5 \pm 3.6$ & $1.04 \pm 0.09$ \\
\hline IBMX, $10^{-3} \mathrm{M}$ & $0.69 \pm 0.04^{*}$ & $0.03 \pm 0.007^{*}$ & $1.29 \pm 0.6^{*}$ & $0.11 \pm 0.05^{*}$ \\
\hline \multicolumn{5}{|l|}{$\operatorname{ATP}_{\gamma} \mathbf{S}(\mathbf{M})$} \\
\hline $10^{-5}$ & $8.7 \pm 2.3$ & $0.32 \pm 0.006$ & $25.1 \pm 6.2^{*}$ & $0.99 \pm 0.09$ \\
\hline $10^{-4}$ & $8.0 \pm 1.9$ & $0.31 \pm 0.007$ & $22.7 \pm 4.0^{*}$ & $0.88 \pm 0.15$ \\
\hline $10^{-3}$ & $6.0 \pm 2.1^{*}$ & $0.25 \pm 0.05^{*}$ & $29.4 \pm 4.1$ & $0.90 \pm 0.13$ \\
\hline
\end{tabular}

The data represent the mean $\pm \mathrm{SE}$ of five separate experiments.

* $P<0.05$ when compared with basal value. stimulated enzyme activity. The ATP analogue 2 MeATP exerted the greatest inhibitory effect. Together, these results suggest the presence of functional $P_{2 y}$ receptors which act to inhibit AVP-stimulated adenylate cyclase activity in LLC-PK membranes. An effect of $\mathrm{P}_{2 \mathrm{y}}$ receptor agonists to inhibit cAMP accumulation in hepatocytes and FRTL thyroid cells has recently been reported $(5,7)$. Our results supporting a $P_{2 y}$ type of ATP receptor in mediating ATP effects are solely dependent upon the rank order potency of several ATP analogues studied in other tissues $(1,3,5,7)$. Thus, further studies will be necessary to document the exact nature of the ATP receptor present in renal epithelial cells (31).

It is possible that some of the effect of ATP $\gamma$ S and other ATP analogues to inhibit agonist-stimulated adenylate cyclase

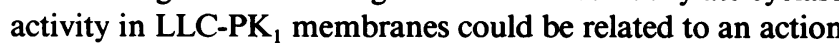
of the ATP analogues to act as a pseudosubstrate for adenylate cyclase. Indeed in plasma membranes, we observed a biphasic effect of ATP $\gamma \mathrm{S}$ to inhibit AVP-stimulated adenylate cyclase activity with modest $(25-40 \%)$ inhibition occurring at $10^{-8}$ through $10^{-4} \mathrm{M}$ and a striking further inhibition occurring at $10^{-3} \mathrm{M}$. Although some of ATP $\gamma \mathrm{S}$ inhibition of AVP-stimulated adenylate cyclase activity may be due to pseudosubstrate effect, particularly at high concentrations of $A T P \gamma S$, there are several factors that suggest the presence of functional external ATP receptors on $L L C-P_{1}$ cells. Thus, at $10^{-4} \mathrm{M}, \mathrm{ATP} \gamma \mathrm{S}$ significantly inhibits AVP-stimulated cAMP accumulation in intact $\mathrm{LLC}_{-} \mathrm{PK}_{1}$ cells. Also, GDP $\beta S$ significantly prevents ATP $\gamma$ S inhibition of agonist-stimulated adenylate cyclase activ-

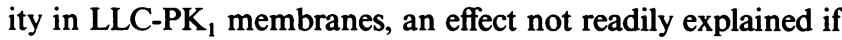
ATP $\gamma$ S were acting solely as a pseudosubstrate. Finally, exposure of intact LLC-PK 1 cells to concentrations of ATP $\gamma$ S from $10^{-10}$ through $10^{-6} \mathrm{M}$ significantly increases protein kinase $\mathrm{C}$ activity in these cells. Together, these observations support the presence of functional ATP-responsive receptors on LLC-PK cells.

We undertook several studies to clarify the mechanism whereby ATP-responsive receptors inhibit agonist-stimulated adenylate cyclase activity. Solubilization of LLC-PK mem- $_{1}$ branes resulted in loss of adenylate cyclase response to AVP. However, in these solubilized membranes, both GTP and forskolin significantly stimulated adenylate cyclase activity and ATP $\gamma$ S inhibited forskolin-stimulated enzyme activity. These findings demonstrate that $\mathrm{ATP} \gamma \mathrm{S}$ can act independent of an AVP receptor to inhibit adenylate cyclase activity. Pretreat-

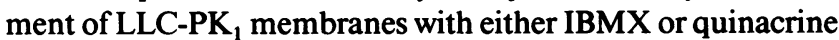
did not prevent $\mathrm{ATP} \gamma \mathrm{S}$ inhibition of adenylate cyclase activity, suggesting that neither $A_{1}$ adenosine receptors nor phospholipase $A_{2}$ are involved in this process.

The effect of $P_{2 y}$ receptor agonists to inhibit adenylate cyclase activity in hepatocytes and in FRTL-5 thyroid cells has been reported to be pertussis toxin sensitive $(5,7)$. We did not find that exposure to very high concentrations of pertussis toxin attenuated the effect of ATP $\gamma \mathrm{S}$ to inhibit either AVP- or forskolin-stimulated adenylate cyclase activity. Previously, in physiologic studies, we have found that pertussis toxin can reverse the effect of $\alpha_{2}$ adrenergic agonists to inhibit AVP action in mammalian collecting tubular epithelia (32). The reasons for the discrepancy between our results in LLC-PK ${ }_{1}$ cells and the results of others in hepatocytes and dedifferentiated thyroid cells are not clear. In other studies in LLC-PK 1 cells, Weinberg and collaborators did not find that pertussis toxin pretreatment attenuates the effect of exogenous ATP to increase free cyto- 
solic calcium activity (19). Also, recent preliminary studies by Lederer et al., in AVP-responsive mammalian collecting tubular cells, found that pertussis toxin does not reverse the inhibitory effect of ATP on AVP-stimulated hydroosmotic response (21). We performed additional studies to explore the possibility that a pertussis toxin-insensitive $G$ protein mediates the effect of ATP $\gamma$ S to inhibit AVP-stimulated adenylate cyclase activity. In these studies, we used GDP $\beta S$, a non-hydrolyzable GTP analogue that prevents $G$ protein activation. In paired studies, GDP $\beta$ S consistently attenuated the effect of ATP $\gamma$ S to inhibit AVP- and forskolin-stimulated adenylate cyclase activity. Our results suggest the possibility that $\mathrm{ATP} \gamma \mathrm{S}$ inhibition of adenylate cyclase activity involves a pertussis toxin-insensitive $G$ protein. However, to date, a pertussis toxin-insensitive $G$ protein linked to inhibition of adenylate cyclase activity has not been demonstrated. Thus, further studies are clearly needed to substantiate and clarify the role of G proteins in ATP inhibition of adenylate cyclase activity in LLC-PK ${ }_{1}$ cells.

In virtually all cell types studied to date, including AVP-responsive $\mathrm{LLC}-\mathrm{PK}_{1}$ and mammalian collecting tubular cells, ATP and its analogues activate a phosphoinositide-specific phospholipase $\mathrm{C}$ with subsequent formation of $\mathrm{IP}_{3}$ and mobilization of intracellular calcium stores $(5-7,19,21,27,28)$. An effect of ATP to activate protein kinase $C$ has not been directly demonstrated. We found that LLC-PK ${ }_{1}$ cells contain a calcium and diacylglycerol activated protein kinase. The specific activity of this enzyme was significantly greater and the basal cellular location of the enzyme different than we observed previously in primary cultures of collecting tubular cells $(22$, 23). In these studies, exposure of intact LLC-PK ${ }_{1}$ cells to the phorbol ester PMA and to ATP $\gamma$ S consistently and significantly increases total protein kinase $\mathrm{C}$ activity. Activation of protein kinase $C$ has been reported to both potentiate and inhibit agonist-stimulated adenylate cyclase activity in AVP-responsive renal epithelial cells $(22,23,33)$. To determine if activation of protein kinase $C$ is responsible for the observed ATP $\gamma \mathrm{S}$ inhibition of adenylate cyclase activity, cells were pretreated with high concentrations of two structurally dissimilar inhibitors of protein kinase $C$. Neither of these agents attenuate the effect of ATP $\gamma \mathrm{S}$ to inhibit AVP-stimulated adenylate cyclase activity, suggesting a protein kinase $C$-independent effect.

In view of suggestions that the process of CAMP hydrolysis may be regulated by ATP, we measured cAMP phosphodiesterase activity in LLC-PK 1 cell fractions. ATP $\gamma \mathrm{S}$ at high concentrations exerts a modest inhibitory effect on cAMP phosphodiesterase activity comparable to that seen previously in homogenized brain and rat kidney $(29,30)$. These observations suggest the potential for ATP to act at more than one site to regulate cAMP metabolism.

The results of our studies suggest that ATP responsive receptors are linked to two signal transduction systems in LLC$\mathrm{PK}_{1}$ cells. Other purinergic receptors, particularly the $\mathrm{A}_{1}$ adenosine receptor, appear coupled to two signal transduction systems in renal epithelial cells $(9,13,19,34,35)$. In this regard, $A_{1}$ receptor agonists inhibit cyclic AMP formation, increase cytosolic calcium activity, and stimulate phosphoinositide turnover $(9,13,19,34,35)$. In other renal epithelial cells, other hormones such as parathyroid hormone and AVP may also be linked to both the protein kinase $A$ and protein kinase $C$ signal transduction pathways $(36,37)$. Our results do not establish if ATP receptors are coupled to the two signal transduction pathways by two separate receptors or by a single receptor with coupling through different $\mathrm{G}$ proteins. Although further studies will be required to clarify this issue, the work of Okajima et al. in rat hepatocytes suggests that distinct ATP receptors are linked to each signal transduction system (5).

In summary, our studies suggest the possibility that functional $P_{2 y}$ purinoceptors are present in LLC-PK $\mathbf{1}_{1}$ cells and are coupled to inhibition of adenylate cyclase and stimulation of protein kinase $\mathrm{C}$ activity. ATP receptor inhibition of adenylate cyclase activity appears independent of $A V P$ and $A_{1}$ adenosine receptors and phospholipase $A_{2}$ and protein kinase $C$ activity. The effects of ATP receptors to inhibit adenylate cyclase activity may be transduced by a pertussis toxin-insensitive $G$ protein. The presence of functional ATP receptors in renal epithelial cells suggests the potential for these receptors to modulate cellular transport processes. Studies in various renal epithelia suggest that ATP receptors may regulate sodium, chloride, and potassium transport $(17,18,20)$. Finally, there are multiple potential sites of origin for extracellular ATP including release during neurotransmission and cellular exocytosis (1).

\section{Acknowledgments}

The authors thank Joyce Fabel for expert secretarial assistance.

This work was supported by funds from the Veterans Administration Research Service and from a National Institutes of Health First Award to Dr. Dixon.

\section{References}

1. Gordon, J. L. 1986. Extracellular ATP: effects, sources and fate. Biochem. J. 233:309-319.

2. Williams, M. 1987. Purine receptors in mammalian tissues: pharmacology and functional significance. Annu. Rev. Pharmacol. Toxicol. 27:315-345.

3. Burnstock, G., and C. Kennedy. 1985. Is there a basis for distinguishing two types of P1-purinoceptors? Gen. Pharmacol. 16:433-440.

4. Charest, R., P. F. Blackmore, and J. H. Exton. 1985. Characterization of response of isolated hepatocytes to ATP and ADP. J. Biol. Chem. 260:1578715794.

5. Okajima, F., Y. Takumitsu, Y. Kondo, and M. Ui. 1987. P2-purinergic receptors are coupled to two signal transduction systems leading to inhibition of cAMP generation and to production of inositol triphosphate in rat hepatocytes. $J$. Biol. Chem. 262:13483-13490.

6. Boyer, J. L., C. P. Downes, and T. K. Harden. 1989. Kinetics of activation of phospholipase $C$ by $P_{2 y}$ purinergic receptor agonists and guanine nucleotides. J. Biol. Chem. 264:884-890.

7. Okajima, F., K. Sato, M. Nagarea, K. Sho, and Y. Kondo. 1989. A permissive role of pertussis toxin substrate G-protein in $\mathrm{P}_{2}$-purinergic stimulation of phosphoinositide turnover and arachidonate release in FRTL-5 thyroid cells. $J$. Biol. Chem. 264:13029-13037.

8. Irving, H. R., and J. N. Exton. 1987. Phosphatidylcholine breakdown in rat liver plasma membranes. J. Biol. Chem. 262:3440-3443.

9. Anderson, R. J. 1991. Adenosine: mechanisms of renal actions. In Contemporary Issues in Nephrology, J. Stein, F. Zeyadeh, and S. Goldfarb, editors. Churchill-Livingstone, Inc., New York. 23:281-296.

10. Spielman, W. S., and C. I. Thompson. 1982. A proposed role for adenosine in the regulation of renal hemodynamics and renin release. Am. J. Physiol. 242:F423-435.

11. Lang, M. A., A. S. Preston, J. S. Handler, and J. N. Forrest. 1985. Adenosine stimulates sodium transport in kidney A6 epithelia in culture. Am. J. Physiol. 249:C330-336.

12. Dillingham, M. A., and R. J. Anderson. 1985. Purinergic regulation of basal and vasopressin-stimulated hydraulic conductivity of rabbit cortical collecting tubule. J. Membr. Biol. 88:277-281.

13. Arend, L. J., W. K. Sonnenberg, W. L. Smith, and W. S. Spielman. 1987. $A_{1}$ and $A_{2}$ adenosine receptors in rabbit cortical collecting tubule cells: modulation of hormone-stimulated cAMP. J. Clin. Invest. 79:710-714.

14. Kelley, G. G., E. M. Poeschla, H. V. Barron, and J. N. Forrest. 1990. A adenosine receptors inhibit chloride transport in the shark rectal gland. J. Clin. Invest. 85:1629-1636.

15. Weihprecht, H., J. N. Lorenz, J. Schnermann, O. Skott, and J. P. Briggs. 1990. Effect of adenosine $A_{1}$ receptor blockade on renin release from rabbit isolated perfused juxtaglomerular apparatus. J. Clin. Invest. 85:1622-1628. 
16. Rorive, G., and A. Kleinzeller. 1972. The effect of ATP and $\mathrm{Ca}^{2+}$ on the cell volume in isolated kidney tubules. Biochem. Biophys. Acta. 274:226-239.

17. Simmons, N. L. 1981 . Stimulation of $\mathrm{Cl}^{-}$secretion by exogenous ATP in cultured MDCK epithelial monolayers. Biochem. Biophys. Acta. 646:231-242.

18. Simmons, N. L. 1981 . Identification of a purine $\left(P_{2}\right)$ receptor linked to ion transport in a cultured renal (MDCK) epithelium. Br. J. Pharmacol. 73:379-384.

19. Weinberg, J. M., J. A. Davis, J. A. Shayman, and P. R. Knight. 1989. Alterations of cytosolic calcium in LLC-PK 1 cells induced by vasopressin and exogenous purines. Am. J. Physiol. 256:C967-C976.

20. Woll, E., J. Pfeilschifter, M. Paalmichl, A. Jungwirth, and F. Lang. 1990. Mechanisms of ATP- and bradykinin-induced activation of potassium channels. Kidney Int. 37:1162a (Abstr.).

21. Lederer, E. D., D. Rouse, M. Leite, W. P. Schilling, and W. N. Suki. 1990 Purinergic modulation of arginine vasopressin action in cortical collecting tubules and cultured cells. Clin. Res. 38:245a (Abstr.)

22. Dixon, B. S., R. Breckon, C. Burke, and R. J. Anderson. 1988. Phorbol esters inhibit adenylate cyclase activity in cultured collecting tubular cells. $\mathrm{Am}$. J. Physiol. 254:C183-C191.

23. Dixon, B. S., R. Breckon, J. Fortune, E. Sutherland, F. R. Simon, and R. J. Anderson. 1989. Bradykinin activates protein kinase $\mathrm{C}$ in cultured cortical collecting tubular cells. Am. J. Physiol. 257:F808-F817.

24. Dixon, B. S., R. Breckon, M. A. Kaehny, M. A. Dillingham, and R. J. Anderson. 1990. Histidine regulation of cyclic AMP metabolism in cultured renal epithelial LLC-PK, cells. J. Biol. Chem. 265:760-766.

25. Solomon, Y., C. Londos, and M. Rodbell. 1974. A highly sensitive adenylate cyclase assay. Anal. Biochem. 58:541-548.

26. Sano, K., D. R. Voelker, and R. J. Mason. 1985. Involvement of protein kinase $\mathrm{C}$ in pulmonary surfactant secretion from alveolar type II cells. J. Biol. Chem. 260:12725-12729.

27. Boeynaems, J. M., and J. D. Pearson. 1990. $P_{2}$ purinoceptors on vascular endothelial cells: physiological significance and transduction mechanism. Trends Pharmacol. Sci. 11:34-37.

28. Cooper, C. L., A. J. Morris, and T. K. Harden. 1989. Guanine nucleotidesensitive interaction of a radiolabeled agonist with a phospholipase C-linked P2ypurinergic receptor. J. Biol. Chem. 264:6202-6206.

29. Cheung, W. Y. 1966. Inhibition of cyclic nucleotide phosphodiesterase by adenosine 5'-triphosphate and inorganic pyrophosphate. Biochem. Biophys. Res. Commun. 23:214-219.

30. Dousa, T., and I. Rychlik. 1970. The metabolism of adenosine $3^{\prime}, 5^{\prime}$-cyclic phosphate. Biochim. Biophys. Acta. 204:10-17.

31. Boyer, J. L., C. L. Cooper, and T. K. Harden. 1990. [ $\left.{ }^{32} \mathrm{P}\right] 3^{\prime}-\mathrm{O}-(4-b e n z o y l)$ benzoyl ATP has a photoaffinity label for a phospholipase C-coupled $\mathbf{P}_{2 y}$ purinergic receptor. J. Biol. Chem. 265:13515-13520.

32. Dillingham, M. A., and R. J. Anderson. 1989. Mechanism of neuropeptide $\mathrm{Y}$ inhibition of vasopressin action in rat cortical collecting tubule. Am. J Physiol. 256:F408-413.

33. Teitlebaum, I. 1990. Cyclic AMP and diacylglycerol: mutually inhibitory second messengers in cultured rat inner medullary collecting tubule cells. J. Clin. Invest. 77:1574-1583.

34. Arend, L. J., M. A. Burnatowski-Hledin, and W. S. Speilman. 1988 Adenosine receptor-mediated calcium mobilization in cortical collecting tubule cells. Am. J. Physiol. 255:C581-C588.

35. Arend, L. J., J. S. Handler, J. S. Rhim, F. Gusovsky, and W. S. Spielman 1989. Adenosine-sensitive phosphoinositide turnover in a newly established renal cell line. Am. J. Physiol. 256:F1067-F1074.

36. Dunlay, R., and K. Hruska. 1990. PTH receptor coupling to phospholipase $\mathrm{C}$ is an alternate pathway of signal transduction in bone and kidney. $A m . J$. Physiol. 258:F223-231.

37. Ando, Y., H. R. Jacobson, and M. D. Breyer. 1988. Two interacting signa transduction pathways regulate collecting duct water transport. News Physiol. Sci. 3:235-240. 